\title{
Pengembangan Paket Bimbingan Perencanaan Studi Lanjut dengan Model Creative Problem Solving Bagi Siswa Sekolah Menengah Atas
}

\author{
Agrery Ayu Nadiarenita, M. Muslihati, Yuliati Hotifah \\ Jurusan Bimbingan dan Konseling, Fakultas Ilmu Pendidikan, Universitas Negeri Malang, \\ J1. Semarang No. 5, Malang, Jawa Timur, Indonesia 65145 \\ E-mail: nadiaagrery@gmail.com
}

Artikel diterima: 13 Desember 2016; direvisi 27 Februari 2017; disetujui 28 Februari 2017

\begin{abstract}
This study aims to produce a package of guidance planning further studies with a model of creative problem solving for high school students who meet the acceptability aspects are aspects accuracy, usability, convenience and attractiveness. The guidance package consists of counselors guide book that contains the steps to the stage of providing guidance in career planning and student guide book that contains the materials and evaluation. The research method was adapted from models of Research and Development (R \& D) procedural Borg \& Gall (1983). Experts and field trials is limited (potential users) are analyzed using inter-rater agreement models (Gregory, 2011). Test validity index subject matter experts, media and potential users counselor showed very high criteria. These products meet very precise criteria, very useful, very easy and very attractive to mean very feasible to use. Based on the test can be concluded that the guidance package product planning further studies have met the acceptance criteria.
\end{abstract}

Keywords: guidance; further studies plan; creative problem solving

\begin{abstract}
Abstrak: Penelitian ini bertujuan untuk menghasilkan produk berupa paket bimbingan perencanaan studi lanjut dengan model creative problem solving bagi siswa SMA yang memenuhi aspek keberterimaan yaitu aspek ketepatan, kegunaan, kemudahan dan kemenarikan. Paket bimbingan tersebut terdiri atas buku panduan konselor yang berisi langkah-langkah pemberian bimbingan sesuai tahapan dalam perencanaan karier dan buku panduan siswa yang berisi materi serta evaluasi. Metode penelitian ini diadaptasi dari model Research and Development (R\&D) prosedural Borg \& Gall (1983). Uji ahli dan uji lapangan terbatas (calon pengguna) dianalisis menggunakan inter-rater agreement model (Gregory, 2011). Indeks validitas uji ahli materi, media dan calon pengguna konselor menunjukkan kriteria sangat tinggi. Produk ini memenuhi kriteria sangat tepat, sangat berguna, sangat mudah dan sangat menarik sehingga bermakna sangat layak untuk digunakan. Berdasarkan uji tersebut dapat disimpulkan bahwa produk paket bimbingan perencanaan studi lanjut telah memenuhi kriteria keberterimaan.
\end{abstract}

Kata kunci: bimbingan; perencanaan studi lanjut; creative problem solving

Perencanaan studi lanjut adalah suatu proses penerapan pengetahuan siswa untuk menyusun rencana secara sistematik berkaitan dengan pendidikan lanjutan untuk mewujudkan masa depan yang lebih baik. Setiap siswa yang lulus dari jenjang Sekolah Menengah Atas (SMA) akan melakukan pengambilan keputusan kariernya. Remaja akhir yang telah menyelesaikan sekolah menengah 
atas, akan melanjutkan studi ke Perguruan Tinggi, sehingga mendorong mereka untuk melakukan pemilihan jurusan (Hariyanto, Dewi, \& Aini, 2014). Pada masa ini individu dapat membuat keputusan dengan segera, konkrit dan realistis berkenaan dengan pekerjaannya di masa depan dengan lebih bertanggung jawab dan konsekuen (Hanggara, 2016). Pendapat tersebut dapat diartikan bahwa pemilihan jurusan merupakan salah satu bagian dalam perencanaan karier siswa.

Parsons (dalam Herr \& Cramer, 1984) mengungkapkan bahwa perencanaan karier berfokus pada tiga aspek yaitu: (1) pemahaman akan diri sendiri, bakat, kemampuan, minat, cita-cita, kelebihan, kekurangan dan penyebabnya; (2) pengetahuan tentang syarat dan kondisi untuk menuju kesuksesan, keuntungan dan kerugian, kepuasan, kesempatan, dan beberapa prospek pekerjaan; (3) penggunaan penalaran yang besar antara diri sendiri dan dunia kerja. Apabila diterapkan dalam konteks perencanaan studi lanjut, maka poin kedua dari pendapat Parsons akan sangat berkaitan dengan informasi studi lanjut masuk ke Perguruan Tinggi. Tujuan dari perencanaan studi lanjut ini membantu siswa melakukan tiga tahapan Parsons, yang disesuaikan dengan kebutuhan siswa di sekolah. Hal tersebut sesuai dengan tujuan bimbingan karier di sekolah. Tujuan bimbingan karier di sekolah yaitu membantu siswa dalam pemahaman diri dan lingkungannya dalam pengambilan keputusan, perencanaan, dan pengarahan kegiatan-kegiatan yang menuju kepada karier, dan cara hidup yang akan memberikan rasa kepuasan sesuai, serasi, dan seimbang dengan dirinya dan lingkungannya (Sukardi, 1987).

Dalam rangka perencanaan studi lanjut, siswa SMA tidak terlepas dari masalah-masalah yang dihadapi oleh siswa, baik di masa sekarang maupun di masa depan. Permasalahan siswa SMA berhubungan dengan tiga tahapan perencanaan studi lanjut. Permasalahan yang dihadapi sebagian besar siswa dalam mempersiapkan masa depannya antara lain: (1) siswa pada umumnya tidak paham dengan potensi yang dimilikinya, sehingga ragu dalam menentukan penjurusan atau bidang studi di Perguruan Tinggi; (2) kurang mengetahui cara memilih program studi; (3) siswa kurang memiliki informasi mengenai jurusan yang tersedia; dan (4) belum matangnya perencanaan siswa mengenai pendidikan maupun pekerjaan yang akan dipilihnya (Syamsiah, 2012). Keempat hal tersebut sering terjadi apabila siswa mencapai usia remaja akhir dan ingin melanjutkan ke jenjang pendidikan yang lebih tinggi.

Siswa cenderung memilih program studi karena tren, tanpa memiliki perencanaan yang matang (Ibrahim, 2012). Hal tersebut berdampak pada gagalnya studi beberapa mahasiswa di Perguruan Tinggi, yang mengalami penyesalan setelah memilih program studitertentu, dan akhirnya memutuskan keluar atau dikeluarkan oleh pihak kampus. Selain itu, dari artikel yang dimuat dalam Okezone. com tertanggal 9 Mei 2016, menunjukkan bahwa kesenjangan antara jumlah pendaftar di Perguruan Tinggi Negeri dengan kuota penerimaan mahasiswa baru masih sangat besar. Apabila siswa tidak mampu mengatasi permasalahan-permasalahan tersebut, akan menghambat proses perencanaan studi lanjutnya. Namun demikian, berdasarkan hasil need assessment yang dilakukan di SMAN 9 Malang, menunjukkan bahwa konselor juga mempunyai keterbatasan dalam memberikan informasi studi lanjut kepada siswa, hal ini disebabkan oleh beberapa faktor. Konselor dalam pandangan siswa kurang dapat memfungsikan perannya dengan baik dalam rangka perencanaan studi lanjut, sehingga siswa hanya memiliki sedikit pertimbangan pada saat harus mengambil keputusan.

Kompleksitas masalah yang dialami oleh siswa pasca lulus SMA membutuhkan penyelesaian yang cepat dan tepat. Hal tersebut menjadi penting karena pengambilan keputusan studi lanjut harus dilakukan dalam batas waktu yang berdekatan dengan penerimaan mahasiswa baru. Masalah yang kompleks ini tidak dapat diselesaikan hanya dengan cara problem solving saja. Helie \& Sun (dalam Isrok'atun, 2012) menyatakan bahwa pendekatan problem solving tidak efisien untuk menyelesaikan permasalahan yang kompleks, yang berkaitan dengan pemahaman terhadap sesuatu atau keraguraguan pada kasus tertentu, pendekatan creative problem solving akan lebih tepat digunakan. Tahapan creative problem solving dielaborasi dalam tahapan perencanaan studi lanjut, yang diungkapkan oleh Parsons menjadi sebuah alternatif pemecahan masalah yang kreatif dan visioner. 
Model creative problem solving adalah suatu model pembelajaran dengan melakukan pemusatan pada pengajaran dan keterampilan pemecahan masalah, dan diikuti dengan penguatan keterampilan (Supardi \& Putri, 2010). Ketika dihadapkan pada suatu pertanyaan, siswa dapat menunjukkan keterampilan memecahkan masalah untuk memilih dan mengembangkan tanggapannya. Tidak hanya dengan cara menghafal tanpa dipikir, keterampilan memecahkan masalah juga memperluas proses berpikir (Pepkin (dalam Supardi \& Putri, 2010)).

Kelebihan penggunaan model creative problem solving yang diterapkan pada setting bimbingan ini, konselor dapat membantu siswa menemukan alternatif pemecahan masalah berkaitan dengan studi lanjut pasca lulus SMA, karena setiap siswa akan menghadapi permasalahan yang berbeda. Dengan berfokus pada alternatif pemecahan masalah, maka diharapkan model creative problem solving ini akan dapat melatih keterampilan perencanaan studi lanjut melalui pembuatan alternatif pilihan. Untuk dapat merencanakan alternatif-alternatif pilihan studi lanjut dengan tepat, siswa diberikan paket bimbingan perencanaan studi lanjut dengan menggunakan langkah-langkah creative problem solving secara sistematis. Langkah tersebut adalah: (1) klarifikasi masalah; (2) brainstorming; (3) evaluasi dan pemilihan ide; dan (4) implementasi (Van Oech-Osborn, dalam Pepkin, 1999). Langkah-langkah tersebut dielaborasi melalui tahapan perencanaan karier, sehingga siswa akan lebih mudah dalam merencanakan dan mengambil keputusan studi lanjut.

Pencapaian tujuan perencanaan alternatif-alternatif pilihan studi lanjut, merupakan upaya preventif terhadap kegagalan siswa pada saat pemilihan studi lanjut, dilakukan dengan mengembangkan paket bimbingan, yang dapat digunakan oleh konselor untuk membantu siswa SMA dalam memberikan layanan bimbingan dan konseling. Paket bimbingan dikembangkan berdasarkan kriteria keberterimaan, yaitu ketepatan, kegunaan, kemudahan, dan kemenarikan. Oleh karena itu, peneliti mengembangkan "Paket Bimbingan Perencanaan Studi Lanjut dengan Model Creative Problem Solving bagi Siswa SMA".

\section{METODE}

Pengembangan paket bimbingan perencanaan studi lanjut dengan model creative problem solving bagi siswa SMA ini merupakan jenis penelitian dan pengembangan. Penelitian ini mengadaptasi prosedur penelitian Borg \& Gall (1983). Dikemukakan Borg \& Gall (1983) bahwa penggunaan sepuluh langkah dalam penelitian pengembangan telah diterapkan oleh banyak peneliti. Langkah-langkah tersebut diadaptasi menjadi langkah-langkah berikut: (1) melakukan penelitian dan pengumpulan data. Pada tahap ini dilakukan studi literatur dan pengumpulan data kebutuhan melalui instrumen angket need assesment dan wawancara pada konselor, (2) Mengembangkan produk. Tahap ini terdiri atas; (a) melakukan perumusan tujuan paket bimbingan; (b) menyusun prototipe produk berupa tujuan, materi paket bimbingan, langkah kegiatan, evaluasi serta refleksi; (3) melakukan uji coba produk. Tahap ini diawali dengan menyusun alat penilaian berupa angket berskala untuk menilai ketepatan, kegunaan, kemudahan dan kemenarikan. Kemudian, dilakukan uji coba produk dengan ahli materi dan media serta uji lapangan terbatas dengan konselor di SMAN 9 Malang. Uji ahli materi dilakukan oleh dua orang dosen Bimbingan dan Konseling yang memenuhi kriteria minimal pendidikan S2 Bimbingan dan Konseling dengan masa kerja minimal 5 tahun. Sedangkan uji ahli media dilakukan oleh dosen Teknologi Pendidikan dan dosen Bimbingan dan Konseling yang mengampu matakuliah media Bimbingan dan Konseling dengan kriteria minimal pendidikan S2 Bimbingan dan Konseling dan masa kerja minimal 5 tahun. Langkah selanjutnya yaitu uji lapangan terbatas dilakukan oleh calon pengguna produk yaitu konselor, dengan kriteria berprofesi sebagai konselor di SMAN 9 Malang minimal masa kerja 5 tahun, dan pendidikan terakhir S1 Bimbingan dan Konseling; (4) melakukan revisi produk berdasarkan penilaian ahli dan calon pengguna, (5) menyajikan produk akhir berupa paket bimbingan perencanaan studi lanjut dengan model creative problem solving yang terdiri atas pedoman konselor dan pedoman siswa. 
Instrumen yang digunakan untuk menilai produk berupa angket berskala dengan memuat kriteria keberterimaan berupa ketepatan, kegunaan, kemudahan dan kemenarikan. Hasil penilaian dianalisis menggunakan analisis kuantitatif dan deskriptif. Data kuantitatif hasil uji ahli dan calon pengguna dianalisis menggunakan inter-rater agreement model (Gregory, 2011), sedangkan data deskriptif dianalisis berdasarkan masukan, saran, dan komentar pada lembar saran.

\section{HASIL}

Hasil pengembangan dari penelitian ini adalah paket bimbingan perencanaan studi lanjut dengan model creative problem solving bagi siswa SMA. Paket bimbingan ini ditujukan kepada konselor SMA guna membantu siswa dalam rangka merencanakan berbagai alternatif pilihan studi lanjut dengan menggunakan model creative problem solving yang dilaksanakan secara berkelanjutan di kelas X, XI dan XII. Produk ini dikembangkan dalam format bimbingan sebanyak 12 kali pertemuan dengan enam topik bimbingan yang masing-masing topik merupakan implementasi dari tahapan perencanaan studi lanjut. Perencanaan studi lanjut pada penelitian ini menggunakan model creative problem solving yang dilakukan dengan menerapkan langkah-langkah: (1) klarifikasi masalah; (2) brainstorming; (3) evaluasi dan pemilihan ide; serta (4) implementasi. Langkah-langkah creative problem solving tersebut diinternalisasikan melalui tahapan perencanaan studi lanjut.

Produk yang dikembangkan tersebut merupakan paket bimbingan untuk konselor dan siswa. Paket bimbingan untuk konselor digunakan sebagai pedoman dalam rangka memberikan bimbingan perencanaan studi lanjut dengan model creative problem solving. Sedangkan paket bimbingan untuk siswa digunakan sebagai pedoman siswa dalam mengikuti kegiatan bimbingan. Adapun isi paket bimbingan untuk konselor adalah sebagai berikut: (1) pendahuluan, pada bab ini memuat rasional pengembangan paket bimbingan, kajian tentang perencanaan studi lanjut bagi siswa SMA dan kajian tentang model CPS dalam perencanaan studi lanjut; (2) petunjuk penggunaan, pada bab ini diuraikan petunjuk umum dan khusus dalam rangka penggunaan produk; (3) rencana pelaksanaan bimbingan, pada bab ini terbagi menjadi enam topik yaitu: (a) topik "Kenali Bakatmu"; (b) topik "Apa Minat Jabatanku?"; (c) topik "Yuk Mengenal Nilai Kariermu"; (d) topik "Informasi Perguruan Tinggi, Why Not?"; (e) topik "Bagaimana Cara Masuk Perguruan Tinggi?"; dan (f) topik "Saatnya Menentukan Masa Depanku". Pada masing-masing topik terdiri atas kompetensi dasar, tujuan bimbingan, langkah-langkah kegiatan, uraian materi, aktivitas, evaluasi dan refleksi; (4) penutup, pada bab ini diuraikan mengenai kesimpulan, saran dan daftar rujukan. Memuat beberapa sumber baik berupa sumber buku, informasi dalam website, dan jurnal yang dapat dijadikan sebagai rujukan peningkatan wawasan konselor tentang perencanaan studi lanjut.

Sistematika paket bimbingan untuk siswa didesain lebih sederhana daripada yang digunakan oleh konselor. Adapun isi paket bimbingan untuk siswa adalah sebagai berikut: (1) pendahuluan, pada bab ini diuraikan rasional pentingnya paket bimbingan perencanaan studi lanjut bagi siswa SMA, petunjuk penggunaan dan garis besar paket bimbingan; (2) aktivitas dan materi bimbingan, pada bab ini diuraikan materi bimbingan yang dibaca oleh siswa dan aktivitas yang harus dilakukan disertai tujuan bimbingan pada masing-masing topik; (3) penutup, pada bab ini diuraikan mengenai kesimpulan dan saran bagi pengguna produk yaitu siswa.

Buku pedoman konselor dan siswa dilengkapi dengan gambar-gambar tema yang sesuai topik bahasan, dengan menggunakan beberapa warna untuk mendukung visualisasi paket bimbingan. Panduan ini dicetak di kertas ukuran B5 dan berjumlah 198 halaman bagi pedoman konselor dan 120 halaman bagi pedoman siswa. Hasil penilaian ahli dan calon pengguna dapat dilihat pada tabel 1 .

Hasil analisis dengan menggunakan rumus inter-rater agreement model menunjukkan bahwa paket bimbingan perencanaan studi lanjut bagi pedoman siswa memiliki indeks uji ahli materi sebesar 1 yang berarti memiliki validitas yang sangat tinggi. Kedua ahli memberikan penilaian dengan relevansi tinggi terhadap 23 butir pernyataan. Hasil analisis dengan menggunakan rumus inter-rater agreement model menunjukkan bahwa paket bimbingan perencanaan studi lanjut bagi pedoman siswa memiliki indeks uji ahli media sebesar 1 yang berarti memiliki validitas yang sangat 
Tabel 1 Hasil Penilaian Paket Bimbingan oleh Ahli Materi, Ahli Media dan Calon Pengguna Produk

\begin{tabular}{lll}
\hline Penilaian Ahli Materi & \multicolumn{1}{c}{ Penilaian Ahli Media } & \multicolumn{1}{c}{ Penilaian Calon Pengguna } \\
Produk
\end{tabular}

tinggi. Kedua ahli memberikan penilaian dengan relevansi tinggi terhadap 19 butir pernyataan.

Hasil analisis dengan menggunakan rumus inter-rater agreement model menunjukkan bahwa paket bimbingan perencanaan studi lanjut bagi pedoman siswa memiliki indeks uji calon pengguna produk (konselor) sebesar 1 yang berarti memiliki validitas yang sangat tinggi. Kedua ahli memberikan penilaian dengan relevansi tinggi terhadap 23 butir pernyataan.

\section{PEMBAHASAN}

Produk hasil penelitian dan pengembangan ini berupa paket bimbingan perencanaan studi lanjut bagi siswa SMA, yang terdiri atas pedoman konselor dan pedoman siswa. Produk ini telah diterima secara teoritis melalui penilaian ahli dan praktis melalui penilaian calon pengguna produk. Selain itu, produk pengembangan ini sudah memenuhi kebutuhan calon pengguna, karena disusun berdasarkan hasil need assessment konselor dan siswa. Produk ini juga telah melalui tahap revisi berdasarkan masukan dari ahli, sebelum dilakukan uji lapangan terbatas dengan calon pengguna produk yaitu konselor.

Aspek ketepatan, kegunaan, kemudahan dan kemenarikan dalam produk ini dapat dilihat dari komponen yang ada di dalam pedoman konselor dan siswa. Aspek-aspek tersebut adalah aspek yang dijadikan pertimbangan utama dalam penentuan keberterimaan produk, baik secara teoritis maupun praktis. Hal ini dapat dilihat berdasarkan hasil penilaian dari ahli dan calon pengguna produk yaitu konselor.

Kedua ahli materi memberikan penilaian dengan relevansi tinggi terhadap 25 butir pernyataan pada pedoman konselor dan 23 butir pernyataan pada pedoman siswa dengan indeks validitas 1 yang berarti termasuk dalam kategori sangat tinggi. Ahli media memberikan penilaian pada pedoman konselor dengan relevansi tinggi terhadap 18 butir pernyataan dan 1 butir pernyataan yang mendapatkan relevansi tinggi dari ahli 1 dan relevansi rendah dari ahli 2, sehingga indeks validitas menunjukkan angka 0,95 yang termasuk dalam kategori sangat tinggi. Sedangkan pada pedoman siswa, kedua ahli media memberikan penilaian dengan relevansi tinggi terhadap 19 butir 
pernyataan dengan indeks validitas 1 yang termasuk dalam kategori sangat tinggi. Calon pengguna produk memberikan penilaian dengan relevansi tinggi terhadap 25 butir pernyataan pada pedoman konselor, dan 23 butir pernyataan pada pedoman siswa dengan indeks validitas 1 yang termasuk dalam kategori sangat tinggi. Berdasarkan penilaian ahli dan calon pengguna tersebut maka produk paket bimbingan untuk konselor dan siswa telah memenuhi aspek keberterimaan produk, yaitu dari segi aspek ketepatan, kegunaan, kemudahan dan kemenarikan.

Produk tersebut memenuhi kriteria ketepatan berdasarkan penilaian ahli dan calon pengguna produk karena materi yang dikembangkan dalam paket bimbingan tersebut sudah mencakup keseluruhan tahapan perencanaan studi lanjut. Perencanaan studi lanjut merupakan suatu proses penerapan pengetahuan siswa untuk menyusun rencana secara sistematik berkaitan dengan pendidikan lanjutan untuk mewujudkan masa depan yang lebih baik. Hal tersebut seperti diungkapkan oleh Parsons (dalam Herr \& Cramer, 1984) bahwa perencanaan karier berfokus pada tiga aspek yaitu (1) pemahaman akan diri sendiri, bakat, kemampuan, minat, cita-cita, kelebihan, kekurangan dan penyebabnya; (2) pengetahuan tentang syarat dan kondisi untuk menuju kesuksesan, keuntungan dan kerugian, kepuasan, kesempatan, dan beberapa prospek pekerjaan; (3) serta penggunaan penalaran yang besar antara diri sendiri dan dunia kerja. Jadi, menurut Parsons, sebelum siswa mengambil keputusan studi lanjut maka siswa harus memahami diri terlebih dahulu dan memahami informasi yang berkaitan dengan studi lanjut. Pada produk paket bimbingan ini tahapan pemahaman diri dijabarkan menjadi tiga topik bimbingan untuk mengenali bakat, minat jabatan dan nilai karier. Sedangkan tahapan informasi perguruan tinggi dijabarkan menjadi dua topik yaitu informasi mengenai bentuk-bentuk perguruan tinggi dan jalur masuk di perguruan tinggi.

Penggunaan model creative problem solving dalam tahapan perencanaan studi lanjut ini dinilai tepat, karena konselor mampu membantu siswa mengidentifikasi permasalahan yang mungkin akan muncul pada waktu pengambilan keputusan studi lanjut. Selain itu, model ini juga tepat untuk membantu siswa mengeksplorasi pilihan studi lanjut. Hal ini sesuai dengan pendapat Super (dalam Munandir, 1996) yang menyatakan dalam teori pelangi kariernya bahwa anak pada usia remaja sedang berada pada tahap eksplorasi karier, sehingga individu akan berusaha untuk memperluas wawasan tentang karier di masa depan. Model creative problem solving juga dapat membantu siswa menemukan berbagai alternatif pilihan studi lanjut. Hal ini senada dengan langkah-langkah creative problem solving yang diungkapkan oleh Van Oech-Osborn (dalam Pepkin, 1999) yaitu: (1) klarifikasi masalah; (2) brainstorming; (3) evaluasi dan pemilihan ide; serta (4) implementasi. Alternatif pilihan studi lanjut dibahas pada tahapan yang kedua sampai keempat pada langkah tersebut, sedangkan langkah pertama mengidentifikasi masalah yang berkaitan dengan masing-masing topik. Oleh karena itu, produk ini juga memenuhi kriteria kegunaan karena berguna sebagai acuan konselor dalam memberikan layanan bimbingan dan konseling dengan model creative problem solving.

Produk ini memenuhi aspek kemudahan dengan kriteria validitas sangat tinggi berdasarkan penilaian ahli dan pengguna produk karena terdapat petunjuk penggunaan yang terdiri atas petunjuk umum dan khusus pada pedoman konselor serta petunjuk penggunaan dan garis besar paket pada pedoman siswa. Bagian rencana pelaksanaan bimbingan pada pedoman konselor, memuat kompetensi dasar, tujuan bimbingan, langkah-langkah kegiatan, uraian materi, aktivitas, evaluasi dan refleksi. Selain itu pada pedoman siswa terhadap tujuan bimbingan, uraian materi, aktivitas siswa, evaluasi dan refleksi. Hal ini memenuhi kriteria paket bimbingan yang diungkapkan oleh Wardani (1981) yaitu terdapat cara yang tertata secara sistematis, yang memudahkan siswa belajar, baik dengan bantuan ataupun tanpa bantuan guru dalam rangka mencapai tujuan tertentu.

Produk ini memenuhi aspek kemenarikan berdasarkan pendapat ahli dan calon pengguna dengan kriteria validitas sangat tinggi, dari sisi kemenarikan layout produk dan dari sisi materi. Dari sisi layout produk, paket bimbingan ini menggunakan ilustrasi gambar yang sesuai dengan isi produk dan judul pada pedoman konselor maupun siswa. Dari sisi materi, paket bimbingan ini menggunakan gambar-gambar yang relevan dengan isi materi sehingga akan menarik siswa untuk membaca dan melakukan aktivitas pada paket bimbingan. 
Penilaian pada paket bimbingan juga dilakukan berdasarkan kritik, saran dan masukan ahli serta calon pengguna, tetapi saran tersebut dipertimbangkan dan dianalisis sebelum dilakukan revisi produk. Penambahan lembar refleksi berdasarkan saran dari ahli materi, karena produk sebelumnya belum terdapat lembar refleksi, sehingga hanya sampai pada evaluasi. Penggunaan ilustrasi gambar siswa juga diperbaiki berdasarkan saran dari ahli media, sehingga ilustrasi wajah siswa tampak lebih muda dari konselor. Saran dari calon pengguna produk yang ditambahkan adalah materi bidik misi pada topik ke lima yaitu mengenai jalur masuk di perguruan tinggi.

Berdasarkan hasil keseluruhan uji coba yang dilakukan peneliti, dapat diketahui beberapa kelebihan dan kelemahan dalam produk paket bimbingan ini. Kelebihan dari produk pengembangan ini disusun berdasarkan hasil need assessment dan telah diuji secara empiris oleh empat dosen uji ahli materi dan ahli media, serta calon pengguna produk. Selain itu, contoh kasus yang diberikan pada setiap topik disesuaikan dengan kondisi siswa, baik dari segi penggunaan bahasa serta kasus-kasus yang umumnya terjadi pada saat siswa akan melakukan pemilihan studi lanjut. Kelemahan paket bimbingan ini terletak pada tahap pengembangan yang hanya sampai pada uji keberterimaannya. Prosedur yang digunakan oleh peneliti hanya sampai pada uji keberterimaan saja dengan alasan bahwa produk pengembangan ini telah disusun berdasarkan hasil need assessment yang dilakukan di SMA Negeri 9 Malang, sehingga paket bimbingan ini sudah memenuhi kebutuhan. Selain itu, apabila dilakukan uji efektifitas, waktu yang dibutuhkan tidak sedikit karena sasaran dari paket bimbingan ini adalah siswa kelas X, XI dan XII. Aspek keefektifan masih belum diuji, diharapkan peneliti selanjutnya dapat melakukan uji keefektifan ini.

\section{SIMPULAN}

Berdasarkan hasil uji ahli dan uji calon pengguna, paket bimbingan ini dinilai telah memenuhi kriteria keberterimaan yaitu ketepatan, kegunaan, kemudahan dan kemenarikan, sehingga produk memiliki indeks validitas dengan kategori sangat tinggi pada masing-masing ahli. Oleh karena itu, paket bimbingan perencanaan studi lanjut dengan model creative problem solving dapat dijadikan sebagai media pelayanan bimbingan dan konseling oleh konselor serta digunakan siswa untuk merencanakan alternatif pilihan studi lanjut.

Konselor diharapkan menggunakan rencana pelaksanaan bimbingan dan konseling yang terdapat pada paket bimbingan perencanaan studi lanjut. Hal ini bertujuan agar proses bimbingan dapat berjalan sesuai dengan tujuan yang diharapkan yaitu siswa mampu merencanakan berbagai alternatif studi lanjut dengan berdasarkan kemampuan dirinya. Sedangkan untuk siswa, dalam pemanfaatan paket bimbingan ini disarankan membaca petunjuk penggunaan paket dengan jelas, sehingga akan memudahkan siswa dalam memahami uraian materi, mengerjakan aktivitas dan pada akhirnya mengerjakan lembar refleksi. Selain itu, bagi peneliti selanjutnya perlu dikembangkan paket pelatihan bagi konselor dalam membantu perencanaan studi lanjut siswa yang berfokus pada keterampilan konselor sebagai helping profession bagi siswa.

\section{DAFTAR RUJUKAN}

Borg, W.R., \& Gall, M.D. (1983). Education Research and Introduction, fourth edition. New York: Longman.

Gregory, R.J. (2011). Psychologycal Testing. History, Principles, and Aplications (6th Ed). Boston: Allyn \& Bacon.

Hanggara, G. S. (2016). Keefektifan "Proses Guru" sebagai Teknik Bimbingan Kelompok dalam Meningkatkan Pengambilan Keputusan Karier Siswa SMK. Jurnal Kajian Bimbingan dan Konseling, 1(4), 148-157. Retrieved from http://journal.um.ac.id/index.php/bk/article/ view/6893 
Hariyanto, D. D., Dewi, E.I., \& Aini S, L. (2014). Hubungan Persepsi tentang Kesesuaian Harapan Orang Tua dengan Diri dalam Pilihan Studi Lanjut dengan Tingkat Stres pada Siswa Kelas XII di Kabupaten Jember. E-Jurnal Pustaka Kesehatan, (Online), 2 (1): 125-131, (http://repository. unej.ac.id/handle/123456789/60716), diakses 1 Februari 2016.

Heer, E.L., \& Cramer, S.H. (1984). Career Guidance And Counseling Through The Life Span. Canada: Little, Brown \& Company Limited.

Ibrahim, R. (2012). Panduan Memilih Perguruan Tinggi. Jakarta: Pusat Data dan Analisis Tempo.

Isrok'atun. (2012). Creative Problem Solving (CPS) Matematis. "Kontribusi Pendidikan Matematika dan Matematika dalam Membangun Karakter Guru dan Siswa" Makalah disajikan pada Seminar Nasional Matematika dan Pendidikan Matematika, Jurusan Pendidikan Matematika ,FMIPA, UNY, Yogyakarta, 10 November 2012. Dalam Eprints UNY, (Online), (http://eprints. uny.ac.id/8094/1/P\%20-\%2047.pdf), diakses 7 Februari 2016.

Munandir. (1996). Program Bimbingan Karier di Sekolah. Jakarta: Departemen Pendidikan dan Kebudayaan Direktorat Jenderal Pendidikan Tinggi Proyek Pendidikan Tenaga Akademik.

Okezone. diakses 9 Mei 2016. Fakta Seputar Hasil SNMPTN 2016, (Online), (http://news.okezone. com/read/2016/05/09/65/1383473/fakta-seputar-hasil-snmptn-2016), diakses 29 Juli 2016.

Pepkin, K. L. (1999). Creative Problem Solving in Math. (Online). (http://www.cimm.ucr.ac.cr/ resoluciondeproblemas/PDFs/Pepkin,Karen.2000.pdf). diakses 12 Februari 2016.

Sukardi, D. K. (1987). Bimbingan Karier di Sekolah-sekolah. Jakarta: Ghalia Indonesia.

Supardi, K. I., \& Putri, I. R. (2010). Pengaruh Penggunaan Artikel Kimia dari Internet pada Model Creative Problem Solving Terhadap Hasil Belajar Kimia Siswa SMA. Jurnal Inovasi Pendidikan Kimia, (Online), 4 (1) : 574-581, (http://download.portalgaruda.org/article. php?article=136474\&val=5666), diakses 7 Februari 2016.

Syamsiah, E. N. (2012). Profil Kematangan Karir Siswa Sekolah Menengah Atas serta Implikasinya Bagi Bimbingan Karir. Skripsi. Bandung: Jurusan Bimbingan dan Konseling UPI Bandung. (Online). (Http://repository.upi.edu), diakses 10 Februari 2016.

Wardani, I.G.A.K. (1981). Pengembangan Paket Belajar. Jakarta: Depdikbud. 